\title{
Biodiversity of mangrove aquatic fauna in Purworejo, Central Java, Indonesia
}

\author{
WIRYANTO $^{1,2}$, SUNARTO ${ }^{1,2}$, SLAMET MARDIYANTO RAHAYU ${ }^{2, \bullet}$ \\ ${ }^{1}$ Department of Biology, Faculty of Mathematics and Natural Sciences, Universitas Sebelas Maret. Jl. Ir. Sutami 36A Surakarta 57 126, Central Java, \\ Indonesia \\ ${ }^{2}$ Program of Bioscience, School of Graduates, Universitas Sebelas Maret. Jl. Ir. Sutami 36A Surakarta 57 126, Central Java, Indonesia. Tel./Fax. +62- \\ 271-663375, "email: slamet.mardiyantorahayu84@gmail.com
}

Manuscript received: 10 January 2017. Revision accepted: 26 August 2017.

\begin{abstract}
Wiryanto, Sunarto, Rahayu SM. 2017. Biodiversity of mangrove aquatic fauna in Purworejo, Central Java, Indonesia. Biodiversitas 18: 1344-1352. Mangrove areas have important roles of ecologic, socio-economic, and socio-culture in ecosystem. Mangrove areas in Purworejo go into degradation as an impact of illegal logging, fishpond area expansion, settlements expansion and extension of agriculture area. All of the activities will influence the communities' structure of mangroves vegetation and aquatic fauna. The purposes of research are to observe (i) biodiversity of mangroves aquatic fauna; (ii) correlation between mangrove vegetation and aquatic fauna; and (iii) the influence of abiotic factors towards biotic condition in research sites. This research was conducted in JuneSeptember 2016 at 3 stations and was determined with purposive sampling method. The research stations are Gedangan (Station 1), Jatikontal (Station 2) and Ngentak (Station 3). Vegetation of mangrove and aquatic fauna were observed with method of line transect and sampling removal. Association between variables (vegetation and aquatic fauna) is analyzed with Pearson Correlation Test. Influence of abiotic factors (physics and chemicals) on biotic (vegetation and aquatic fauna) is analyzed with t-test and regression test. According to the research, 34 species of aquatic fauna are from mangroves area of Purworejo. Highest value of aquatic fauna is found in Station 3 (ID 2.50). Pearson correlation test between vegetation and aquatic fauna obtains $r$ value of 0,104 . The t-test results a significant difference (sig 0.000) between abiotic factors and biotic condition and shows the impact of changes on both. Further test with regression method also indicates a weak impact on changes on abiotic factors towards biotic condition $\left(\mathrm{r}^{2} 0.032\right)$.
\end{abstract}

Keywords: mangrove, biodiversity, aquatic fauna, Purworejo

\section{INTRODUCTION}

The mangroves ecosystem has important roles in ecosystem, especially in terms of ecological, environmental, biological, medical and environmental values (Baran 1999). Mangrove is known as a coastal ecosystem with the highest biological productivity (Alongi 2002). Mangrove forests have important ecological functions such as natural carbon absorber, pollutant remediation, abrasion prevention, intrusion and storm prevention. They can be as habitat of growth and development of diverse aquatic fauna.

The mangroves have an ability to increase product of fishery activity which was reaching $23 \%$ from normal value (Anneboina and Kumar 2012). Mangrove also played a vital role to defend coastal area from abrasion by giving stability to the sediment with their bonding roots. Mangrove is a pollutant filter of the sea, it maintains the water quality and clarity; and also traps the sediment from land (Monsef and Smith 2008).

The roots of Acanthus ilicifolius can be used as medicine since it has the content of an ethyl acetat, ethanol and methanol. Their contents have an antimicrobia effects on Vibrio harveyi, Aeromonas hydrophila and Escherichia coli (Sreenivasa et al. 2015). An extract of leaves and bark of Sonneratia alba was an antibacteria for pathogen such as Bacillus cereus, Staphylococcus aureus, E. coli, Salmonella typhimurium and Klebsiella pneumoniae. An extract of roots and barks of Avicennia lanata was an antibacteria for pathogen likes E. coli, S. aureus and $K$. pneumoniae while an extract of leaves and barks of Ceriops tagal have similar utilization as antibacteria for S. aureus (Eldeen et al. 2015).

Purworejo District is part of Central Java Province, Indonesia which is located at south coast of the island. Mangroves areas on Purworejo are located in sub districts of Purwodadi, Ngombol and Grabag (Local Government of Purworejo 2011). Mangrove areas on Purworejo are degrading as the effect of illegal logging, fishponds expansion, expansion of settlements and extension of agriculture area.

The pond areas in Purworejo have increased from 136 hectares (2009) to 250 hectares in 2015 (Regional Development Planning Board of Purworejo 2016). Logging and land conversion act are the major factors of mangroves area degradation in Purworejo. Reduction of mangrove area will impact on changes of abiotic factors which can influence aquatic fauna life in association with mangrove vegetation.

Indonesia has a largest area of mangroves. However, the areas are reduced until 1.5 million hectares since 1980 (Spalding et al. 2010). Mangrove degradation was driven by a rapid growth of the local population and their economy which trigger an input of pollutant from various anthropogenic activities (Dsikowitzky et al. 2011). The 
mangrove degradation in Purworejo was aligned with a historical research by Ilman et al. (2016). The research found out that an aquaculture development (tambaks) was main factor of degradation, added by a change of land use into a palm oil plantation. According to Giri (2008) in Asia, a land conversion into agriculture and aquaculture reduced $12 \%$ of mangrove area.

A community of mangrove fauna is divided into two main groups: the terrestrial fauna and the aquatic fauna. The group of terrestrial fauna generally occupies higher part of mangroves, for example, insects, snakes, primates and birds. This group doesn't have a specific adaptability to survive on mangroves. This group will pass most of their life cycle outside the marine water but still hunt for the marine fauna, as their main food sources, taking advantage of low tide time. The groups of aquatic fauna consists of two types, (i) the type living in the water column, including fish and shrimp; (ii) the type living on the substrates either in hard or soft type, including crabs, clams and another type of invertebrates (Bengen 2001).

The mangrove degradation will reduce an ecosystem service related with a human welfare and a sustainability of mangrove ecosystem itself (Oudenhoven et al. 2015). A continuous degradation of mangroves in Purworejo will cause reduction on biodiversity organisms. Until today, research about biodiversity of aquatic fauna in mangrove area of Purworejo District is still rare. Actually, in a research about biodiversity, a correlation between vegetation and aquatic fauna and the influence of abiotic factor was important to be conducted.

The objectives of the research are to observe (i) biodiversity of mangroves aquatic fauna, (ii) correlation between mangrove vegetation and aquatic fauna, and (iii) the influence of abiotic factors towards biotic condition in research sites.

\section{MATERIALS AND METHODS}

\section{Study area}

This research is conducted at mangrove area of Purworejo District, Central Java, Indonesia. The research Station is determined with purposive sampling method. Station 1 is located in Gedangan Village and Station 2 is located in Jatikontal Village, both are in Purwodadi Subdistrict and near settlements and beach tourism site of Jatikontal. Station 3 is located near paddy field area of Ngentak Village, Ngombol Subdistrict. The entire mangrove is located in the riverbanks of Pasir River, that empties into the estuary of Bogowonto River in the Indian Ocean.
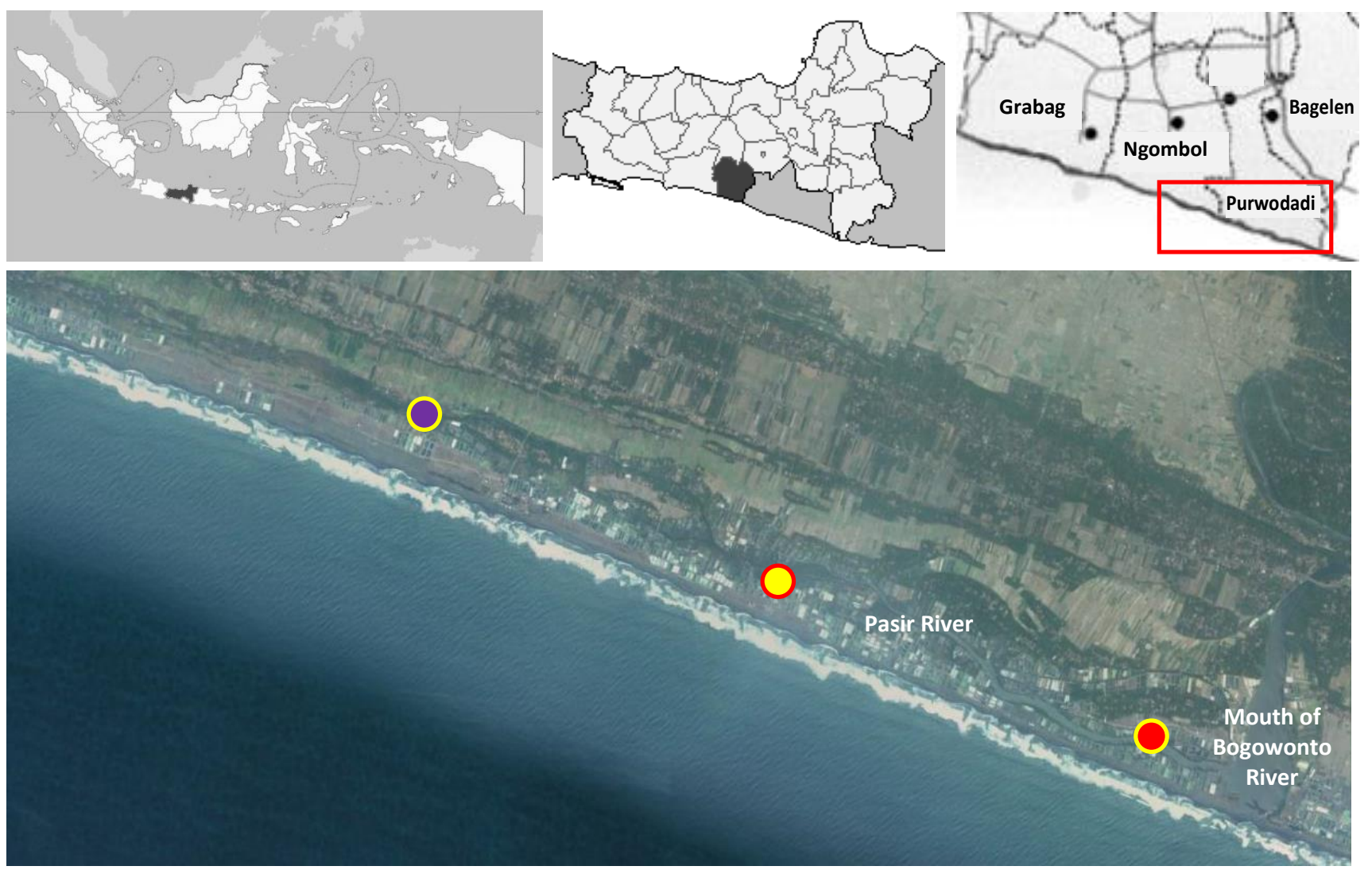

Figure 1. Study site of mangrove aquatic fauna in Subdistrict of Purwodadi, District of Purworejo, Central Java, Indonesia. Note:

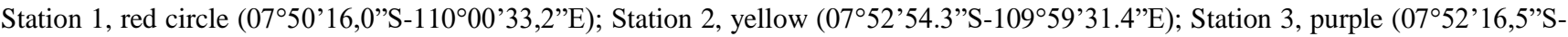
$\left.109^{\circ} 58^{\prime} 20,4 ’ \mathrm{\prime}\right)$ 


\section{Materials}

The research equipments are wooden pegs, measuring roll meter, identification guidelines of vegetation and aquatic fauna of mangrove, thermometer, DO-meter, $\mathrm{pH}$ meter, refractometer, aquatic fauna capturing tool (pintur and net trap), icebox, digital camera, stationary and laptop. The materials of research are papers and plastics, aquadest and alcohol. Diversity of mangrove vegetation is observed with transect line plots method, which is in accordance to the guidelines in Decree of Minister of Environmental Number 201 Year 2004. Type of aquatic fauna is observed with removal sampling method.

\section{Procedures}

Observation of mangrove vegetation biodiversity

Transect is assembled in each station, and it consists of 20 plots and each of plot is divided again into sub plots. Minimum length suitable for mangrove vegetation analysis is $300 \mathrm{~m}$ (Onrizal 2008). The size of plants and sub plots are: herbs (sprouts' size $<1.5 \mathrm{~m}$ ) using sub plot size of $2 \mathrm{~m}$ x $2 \mathrm{~m}$, shrubs (height $=1.5 \mathrm{~m}$ and diameter of the $\operatorname{rod}<10$ $\mathrm{cm}$ ) using sub plot size of $5 \mathrm{~m} \mathrm{x} 5 \mathrm{~m}$; and trees (trees with diameter of $\operatorname{rod}=/>10 \mathrm{~cm}$ ) using sub plot size of $10 \mathrm{~m} \mathrm{x}$ $10 \mathrm{~m}$. Identification of mangrove vegetation refers to Noor et al. (2012).

\section{Observation of mangrove aquatic fauna}

Catching aquatic fauna is done with traditional capturing tool. This implementation is intended to optimize catching results so that a more diverse aquatic fauna can be collected. Identification of aquatic fauna refers to $\mathrm{Ng}$ and Sivasothi (2001).

\section{Measuring of abiotic factors}

The measurement of water salinity is conducted with hand refractometer instrument. The measurement of $\mathrm{pH}$ level is conducted with $\mathrm{pH}$ meter. The measurement of water temperatures is conducted with water thermometer. The measurement of dissolved oxygen values is conducted with DO-meter. Soil textures are determined with feeling method, namely doing the massaging and to feel the soil samples using bare fingers to specify substrates condition (Hardjowigeno 1989).

\section{Data analysis}

Species density

Species diversity has been analyzed refer to Indriyanto (2012):

$$
\mathrm{K}=\frac{\text { sum of individuals }}{\text { total area of sample plots }}
$$

\section{Diversity indices}

Analysis of diversity has been conducted for mangrove vegetation and aquatic fauna which had been caught with capturing tool. The biodiversity is calculated with Diversity Index of Shannon Wiener which is formulated as follows:

$$
H^{\prime}=-\sum \frac{n i}{N} \ln \frac{n i}{N}
$$

Note:

$\mathrm{H}^{\prime} \quad$ : the diversity index of Shannon Wiener

ni : sum of individual of species in all individuals

$\mathrm{N} \quad$ : total numbers of individuals

Results of Shannon Wiener diversity index calculation should be categorized below (Odum and Barrett 2009):

$$
\begin{aligned}
& \mathrm{H}^{\prime}<1: \begin{array}{l}
\text { Low diversity, low abundance, low of } \\
\text { communities stability }
\end{array} \\
& 1 \leq \mathrm{H}^{\prime} \leq 3: \begin{array}{l}
\text { Moderate diversity, moderate abundance, } \\
\text { moderate of communities'stability. }
\end{array} \\
& \mathrm{H}^{\prime}>3 \quad \text { High diversity, high abundance, high of } \\
& \text { communities stability }
\end{aligned}
$$

\section{Correlation between mangrove vegetation and aquatic fauna}

Correlation analysis between researched variable (aquatic fauna and mangrove vegetation) is conducted with Product Moment Pearson Test. The analysis is intended to determine level of relationship between variables.

\section{Influence of abiotic factors on mangrove vegetation and aquatic fauna condition}

The variables of research are categorized into independent and dependent variable. In this research, the independent variables are abiotic factors such as temperatures, $\mathrm{pH}$, salinity, dissolved oxygen (DO) and substrates texture. The dependent variables are vegetation of mangrove and aquatic fauna. Influence of independent variable toward dependent variable values are analyzed with T-Test and Regression Test. All of the statistics matters are performed with the assistance of SPSS 20 software.

\section{RESULTS AND DISCUSSION}

\section{The diversity of mangrove aquatic fauna}

Aquatic fauna is observed in mangrove area of Purworejo District and it consists of 19 families and 34 species (Table 1, Figure 2). Mugil cephalus is a common species found in all stations and belongs to Family of Mugilidae. This condition is possible since the characteristic of mobility of M. cephalus which prefers to clump in surface area of water column. Family of Mugilidae is classified as group of fish with excellent adaptation ability. Thus, they would be found in almost all type of waters, especially in estuary, sub-tropic and tropical ocean, such as Indo-Pacific and South China Sea until Australia (Carpenter and Niem 1999).

Scylla serrata (mud crabs or mangrove crabs) and Uca rosea (rose fiddler crabs) are discovered in all research station. This condition is influenced by the type of substrates, a soft sandy loam. Crabs are categorized as invertebrates and considered as aquatic fauna of mud substrates in mangrove ecosystem. According to 
Supriharyono (2007), aquatic fauna of mangrove ecosystem is divided into two main groups: burrowing species and epifauna (species which have life cycle in surface of the substrates). Crabs are categorized as epifauna, especially genus $U c a$ and Family Portunidae. Kathiresan and Bingham (2001) explained that the distribution and the presence of crabs in mangrove ecosystem may be affected by some environmental factors including mangrove litter, substrates character and salinity.

Faunus ater have a highest density in Station 1 and II. This species is a kind of macrozoobenthos which have ability to adapt in Pasir River by immersing themselves into waters, having low mobility and ability to catch their prey, and also having a long life cycle and a relative high density in specific area (Pong-Masak and Pirzan 2006). Key factors of life sustainability on aquatic fauna are the ability to adapt in an environment with specific character (Strong et al. 2008), high reproduction ability and the absence of predator species (Marwoto and Istianingsih 2014).

Channa striata have highest density in Station 3. This condition is influenced by adaptation ability of the species in mangrove ecosystem. Station 3 is located in relatively far away from settlement. Thus, Station 3 will have a relatively low interfere of anthropogenic activities, especially from the hunt of fish, such as $C$. striata. The density of $C$. striata is also affected by the existence of scrubs (lower plants) which is an ideal habitat for this fish species.

The diversity index of aquatic fauna in Station 1, 2 and 3 could be categorized as moderate. Values of each diversity index is 2.30 (1), 2.22 (2) and 2.50 (3). This condition indicates a moderate complexity of aquatic fauna community, as an effect of a good interaction between species. Biodiversity can be implemented to measure communities' stability. Definition of communities' stability is an ability of a community to protect their own stability by themselves.

Polychaeta is known as common group in mangroves. But, this group will never be found in Java Island. Polychaeta is usually found in mangroves area outside Java Island.

Table 1. Mangrove aquatic fauna observed in mangrove area of Purworejo District, Central Java, Indonesia

\begin{tabular}{|c|c|c|c|c|c|}
\hline \multirow{2}{*}{ Class } & \multirow{2}{*}{ Family } & \multirow{2}{*}{ Species } & \multicolumn{3}{|c|}{ Density (individuals/m²) } \\
\hline & & & Station 1 & Station 2 & Station 3 \\
\hline \multirow[t]{10}{*}{ Actinopterygii } & Gobiidae & Periophthalmus novemradiatus & 0.290 & 0.028 & - \\
\hline & & Boleophthalmus boddarti & 0.118 & 0.017 & - \\
\hline & Channidae & Channa striata & 0.012 & 0.010 & 0.079 \\
\hline & Bagridae & Mystus nigriceps & 0.010 & 0.010 & 0.011 \\
\hline & Cichlidae & Oreochromis mossambicus & 0.009 & 0.013 & - \\
\hline & Mugilidae & Mugil cephalus & 0.036 & 0.074 & 0.010 \\
\hline & Osphronemidae & Trichogaster trichopterus & - & - & 0.063 \\
\hline & Anabantidae & Anabas testudineus & - & - & 0.049 \\
\hline & Synbranchidae & Monopterus albus & - & - & 0.017 \\
\hline & Anguillidae & Anguilla bicolor & - & - & 0.012 \\
\hline \multirow[t]{16}{*}{ Malacostraca } & Penaeidae & Penaeus monodon & 0.015 & 0.013 & - \\
\hline & & Penaeus sp. & - & - & 0.019 \\
\hline & Alpheidae & Alpheus microrhynchus & 0.006 & - & 0.014 \\
\hline & & Alpheus euphrosyne & 0.008 & - & - \\
\hline & Palaemonidae & Macrobrachium equidens & - & - & 0.028 \\
\hline & Portunidae & Scylla serrata & 0.020 & 0.008 & 0.007 \\
\hline & & Scylla paramamosain & 0.010 & - & - \\
\hline & Ocypodidae & Uca annulipes & 0.080 & 0.013 & - \\
\hline & & Uca crassipes & 0.010 & 0.005 & - \\
\hline & & Uca paradussumieri & 0.020 & 0.007 & - \\
\hline & & Uca rosea & 0.017 & 0.007 & 0.008 \\
\hline & & Uca tetragonon & 0.013 & 0.011 & - \\
\hline & & Uca vocans & 0.026 & 0.009 & - \\
\hline & & Uca vomeris & 0.060 & 0.012 & - \\
\hline & Sesarmidae & Chiromantes eumolpe & 0.008 & 0.011 & 0.009 \\
\hline & & Metopograpsus sp. & - & 0.014 & 0.011 \\
\hline \multirow[t]{2}{*}{ Gastropoda } & Pachychilidae & Faunus ater & 0.441 & 0.216 & - \\
\hline & Potamididae & Cerithidea obtusa & 0.045 & - & - \\
\hline \multirow[t]{2}{*}{ Bivalvia } & Corbiculidae & Polymesoda expansa & 0.069 & - & - \\
\hline & \multicolumn{2}{|c|}{ Diversity index of Shannon Wiener } & 2.30 & 2.22 & 2.50 \\
\hline
\end{tabular}




\section{The diversity of mangrove vegetation}

Identification on mangrove vegetation determines the existence of 15 families and 18 species in the mangrove area of Purworejo District, according to Noor et al. (2012) (Table 2, Figure 3). Family of Rhizophoraceae, Sonneratiaceae, Arecaceae, and Asteraceae are discovered in all of the research station. Family of Rhizophoraceae consists of 2 species, i.e. Rhizophora mucronata and Rhizophora stylosa. Family of Sonneratiaceae consists of 2 species, i.e. Sonneratia alba and Sonneratia caseolaris. Family of Arecaceae consists of only single species, Nypa fruticans. Family of Asteraceae is similar with Arecaceae which is one species only, Wedelia biflora. Some of the species are defined as mangrove species, based on their ability and conformity to adapt in a specific environmental condition of the mangrove ecosystem. The specific condition could be described as specific condition of abiotic which is dominated by sandy loam substrates.

Definition of density is sum of individuals of organisms per total research area. Tomlison (1994) defines mangrove density as sum of trees of specific type of mangrove in specific monitoring areas. Density of species is associated with distance of tree, sum of individuals, species of mangrove plants and the extents of research area. The value of density ratio will depends on sum of observed individuals which formed positive correlation in between. In this research, the value of mangrove density on specific phases of plant varies in each station (Table 3).

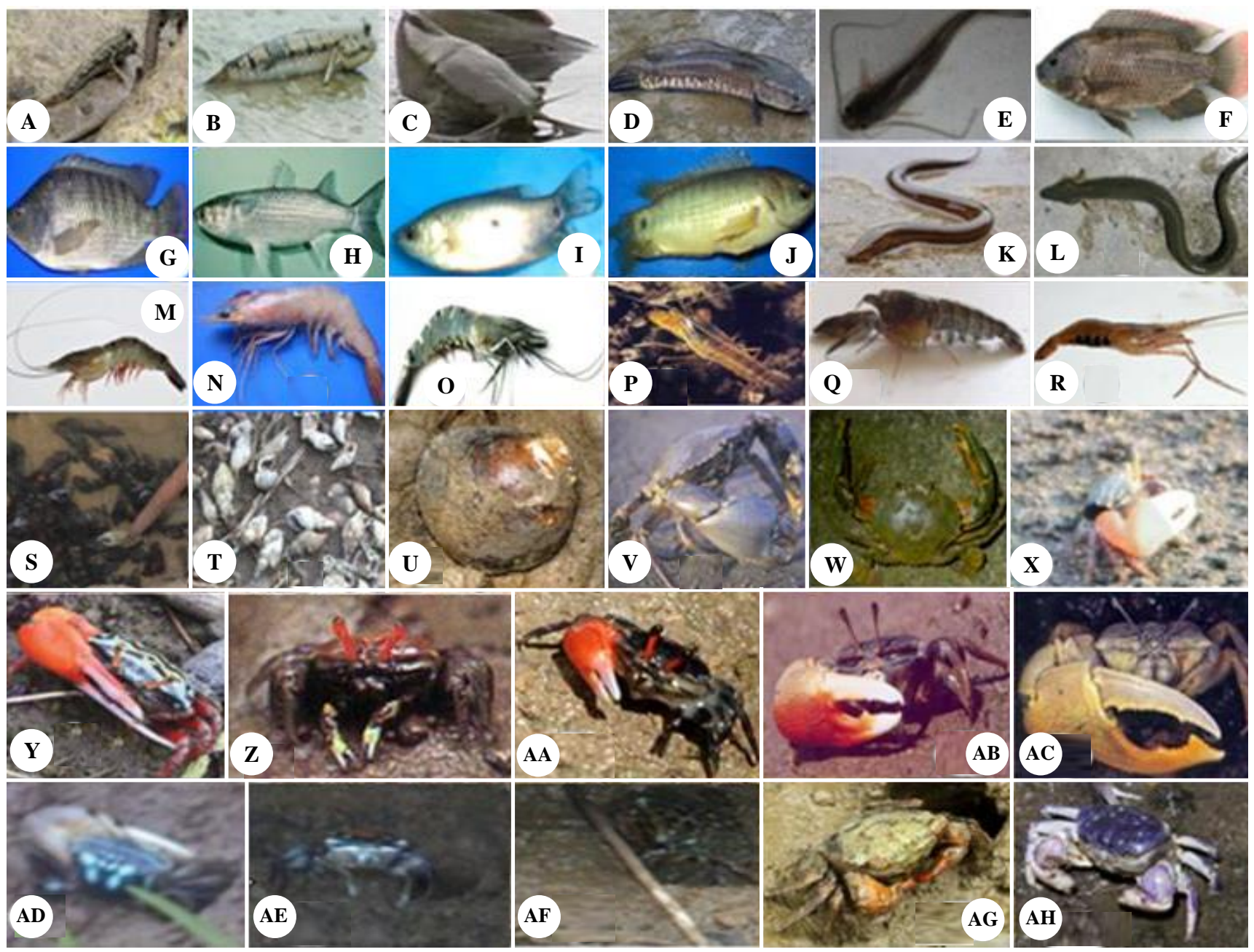

Figure 2. Diversity of aquatic fauna in Mangrove Area of Purworejo District, Central Java, Indonesia. Note: A. $P$. novemradiatus, B. $B$. boddarti, C. C. batrachus, D. C. striata, E. M. nigriceps, F. O. mossambicus, G. O. niloticus, H. M. cephalus, I. T. trichopterus, J. A. testudineus, K. M. albus, L. A. bicolor, M. P. monodon, N. P. merguiensis, O. Penaeus sp., P. A. microrhynchus, Q. A. euphrosyne, R. M. equidens, S. F. ater, T. C. obtusa, U. P. expansa, V. S. serrata, W. S. paramamosain, X. U. annulipes, Y. U. crassipes, Z. U. paradussumieri, AA. U. rosea, AB. U. tetragonon, AC. U. vocans, AD. U. vomeris, AE. C. eumolpe, AF. Metopograpsus sp., AG. $P$. bidens, AH. S. germaini 
Table 2. List of discovered plants species in mangrove area of Purworejo, Central Java, Indonesia

\begin{tabular}{lll}
\hline Family & Species & Station \\
\hline Acanthaceae & Acanthus ilicifolius & 1,2 \\
Arecaceae & Nypa fruticans & $1,2,3$ \\
Asclepiadaceae & Calotropis gigantea & 1,2 \\
Asclepiadaceae & Gymnanthera paludosa & 1,2 \\
Asteraceae & Wedelia biflora & $1,2,3$ \\
Convolvulaceae & Ipomoea pescaprae & 1,2 \\
Cyperaceae & Scirpus sp. & 1 \\
Malvaceae & Hibiscus tiliaceus & 1,2 \\
Molluginaceae & Sesuvium portulacastrum & 3 \\
Passifloraceae & Passiflora foetida & 2 \\
Poaceae & Setaria sphacelata & 3 \\
Pteridaceae & Acrostichum speciosum & 3 \\
Rhizophoraceae & Rhizophora mucronata & 1,3 \\
Rhizophoraceae & Rhizophora stylosa & 2 \\
Rubiaceae & Morinda citrifolia & 2 \\
Sonneratiaceae & Sonneratia alba & 1 \\
Sonneratiaceae & Sonneratia caseolaris & 2,3 \\
Verbenaceae & Stachytarpheta jamaicensis & 2 \\
\hline
\end{tabular}

Table 3. Density of species in mangrove area of Purworejo, Central Java, Indonesia

\begin{tabular}{|c|c|c|c|c|}
\hline \multirow{2}{*}{ Station } & \multirow{2}{*}{ Species } & \multicolumn{3}{|c|}{ Density (ind./ha) } \\
\hline & & Trees & Shrubs & Herbs \\
\hline \multirow[t]{11}{*}{1} & R. mucronata & 400 & 7260 & 71125 \\
\hline & N. fruticans & 20 & 40 & 500 \\
\hline & H. tiliaceus & 5 & 160 & 125 \\
\hline & S. alba & 15 & - & - \\
\hline & G. paludosa & - & - & 45375 \\
\hline & A. ilicifolius & - & - & 20625 \\
\hline & I. pescaprae & - & - & 29500 \\
\hline & C. gigantea & - & - & 375 \\
\hline & Scirpus sp. & - & - & 16625 \\
\hline & W. biflora & - & - & 4250 \\
\hline & Sum total & 440 & 7460 & 188500 \\
\hline \multirow[t]{13}{*}{2} & N. fruticans & 185 & 60 & 500 \\
\hline & R. stylosa & 15 & 860 & 8500 \\
\hline & S. caseolaris & 210 & 1380 & 21500 \\
\hline & H. tiliaceus & - & 100 & \\
\hline & M. citrifolia & - & 20 & - \\
\hline & G. paludosa & - & - & 44500 \\
\hline & A. ilicifolius & - & - & 26375 \\
\hline & S. jamaicensis & - & - & 30125 \\
\hline & I. pescaprae & - & - & 13750 \\
\hline & P.foetida & - & - & 3500 \\
\hline & C. gigantea & - & - & 2125 \\
\hline & W. biflora & - & - & 1125 \\
\hline & Sum total & 410 & 2420 & 152000 \\
\hline \multirow[t]{9}{*}{3} & S. alba & 190 & 340 & 15125 \\
\hline & S. caseolaris & 105 & 640 & 6375 \\
\hline & N. fruticans & 25 & 140 & 250 \\
\hline & R. mucronata & - & 40 & - \\
\hline & A. speciosum & - & - & 27250 \\
\hline & S. portulacastrum & - & - & 62625 \\
\hline & W. biflora & - & - & 4125 \\
\hline & S. sphacelata & - & - & 30875 \\
\hline & Sum total & 320 & 1160 & 146625 \\
\hline
\end{tabular}

In herbs phase, the highest density value of mangrove plants is $R$. mucronata which is obtained from Station 1 (71125 ind./ha). R. mucronata is purposely planted in Station 1 as parts of mangrove rehabilitation. Similar with herbs phase, $R$. mucronata becomes the species with highest density on shrubs phase (7260 ind./ha). $R$. mucronata is usually sprouted in a clump, either near or on the riparian zones. This species have an ability to bloom all over the year and germinate on the parents plants. The plants will be released as propagules which stick on the substrates as new plants. $R$. mucronata prefers an inundation area as suitable habitat, similar with the condition of Pasir River.

Similar with other phases, phase of tree on mangrove plants results $R$. mucronata as species with highest density in Station 1 (400 ind./ha). This condition is influenced by regeneration type of $R$. mucronata which happened in seeds form with the help of tidal waves. Tidal waves will facilitate the deployment of seeds throughout the mangrove areas. The seeds have roots in both end which uses as the fastening tool on substrates on low tide. This condition will enable the plants to grow upright. Supardjo (2008) described that $R$. mucronata is a kind of pioneer plants with ability to grow on softly mud.

Its adaptability on brackish water with extreme salinity influences the density value of $R$. mucronata. The flora communities in mangrove forest have undergone an adaptation and specialization process as natural mechanism to survive on an environment which has high salinity levels (Kustanti 2011). The adaptability of mangrove plants is by removing the salt excess inside their tissues (Indriyanto 2012). Thus, they could grow better in mangrove ecosystem. Highest value of density on $R$. mucronata correlates with reproductive ability. This species has propagules with compliant shapes and attributes to survive in extreme condition. The propagules have a big and elongated shape, are easy to spread by sea-waves and have plentiful reserves of food.

Biodiversity of mangrove is assessed with diversity index of Shannon Wiener. Analysis of biodiversity is used to measure the stability of community which has a definition as ability of specific community to protect themselves in a harmony against the occurrence of disruption on their components. Diversity index is also used to measure an abundance of species based on the numbers of species and sum of individuals in specific location. Variation in community has positive correlation with the numbers of species. Diversity index is significantly influenced by numbers of species and sum of individuals. According to the research, value of diversity index in each station varies (Figure 3).

Diversity index of mangrove vegetation on herbs phase can be categorized as moderate. This condition is obtained in all stations. Highest value of biodiversity is observed in Station 2 (1.84) and the lowest is in Station 3 (1.49). It means that the ecological pressure is on moderate level in research location. The observation in Station 2 gives result that 10 species of mangrove plants are found on herbs phase. The species consist of $S$. caseolaris, $R$. stylosa, $N$. fruticans, G. paludosa, A. ilicifolius, S. jamaicensis, I. 
pescaprae, P. foetida, C. gigantea, and W. biflora. While, the observation in Station 3 results 7 species of mangrove plants on herbs phase, namely: $S$. alba, S. caseolaris, $N$. fruticans, A. speciosum, S. portulacastrum, W. biflora, and S. sphacelata.

Diversity index of mangrove vegetation on shrubs phase is classified as low level in Station 1 and II (H' value: 0.14 and 0.95 ) while in other station (Station 3 ), it is classified as moderate level (1.06). Four species are obtained in Station 3, including $S$. alba, S. caseolaris, $R$. mucronata, and $N$. fruticans while only three species are obtained in Station 1 namely $R$. mucronata, N. fruticans, and H. tiliaceus.

Diversity index of mangrove vegetation on trees phase are categorized as low level in all station. The highest diversity index is obtained in Station 3 (0.87) and the lowest one is in Station 1 (0.39). It means that the ecological pressure is on high level, it was an effect of many environmental problems (probably from anthropogenic activities). Observation of Station 3 results 3 species of mangrove plants on the tree phase, consisting of S. alba, S. caseolaris and N. fruticans. The abundance levels on each species are relatively in similar values. Observation of Station 1 gives result of 4 species of mangrove plants on trees phase, consisting of $R$. mucronata, S. alba, N. fruticans, and $H$. tiliaceus. The abundance level of each species in this Station is significantly different.

\section{Relation between vegetation and aquatic fauna of mangrove}

Correlation test between diversity index of vegetation and aquatic fauna obtains a negative weak correlation between both of the variables on all stations (R:-0.104). These results mean a weak and probably no significant correlation between vegetation and aquatic fauna in research location. The increase of aquatic fauna diversity will reduce the vegetation diversity (Figure 4). This condition is influenced by the existence of the herbivore and the climber species which consuming and damaging mangroves. The species categorized as herbivore and climbers are for example Metopograpsus sp., C. eumolpe and S. germaini.

Zakaria and Rajpar (2015) explain that Marudu Bay mangrove habitats harbored a diversity of fauna species including 22 aquatic invertebrate species (encompassing 11 crustacean species, six mollusk species and four worm species) and 36 fish species. The difference results about the vegetation and aquatic fauna between Purworejo and Marudu mangrove are due to different location and vegetation structure there.

Diversity of aquatic fauna illustrated that mangrove area in Purworejo serve as a nursery ground for various juvenile fish communities. It may be because these areas are rich in invertebrate assemblages such as crustaceans and mollusks. In addition, the extensive root systems of mangroves create habitat heterogeneity and complexity, offering suitable foraging sites for juvenile fishes and protecting them from predators by reducing their visibility. Habitat heterogeneity and complexity is a major factor that influences fauna diversity (Kovalenko 2012).

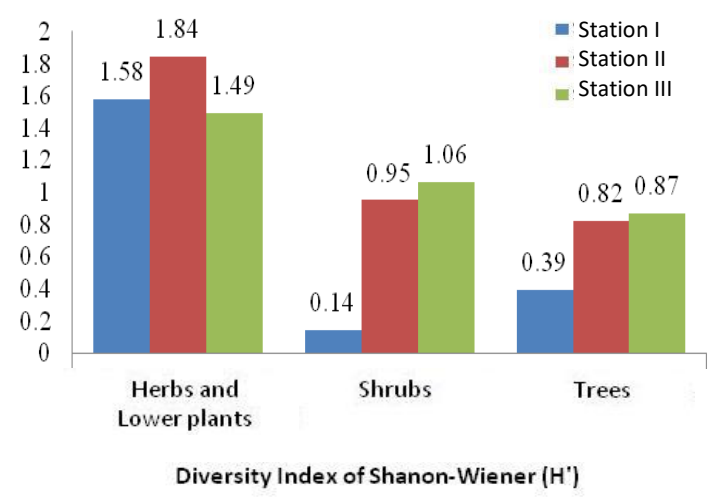

Figure 3. Diversity index of mangrove vegetation in mangrove area of Purworejo, Central Java, Indonesia

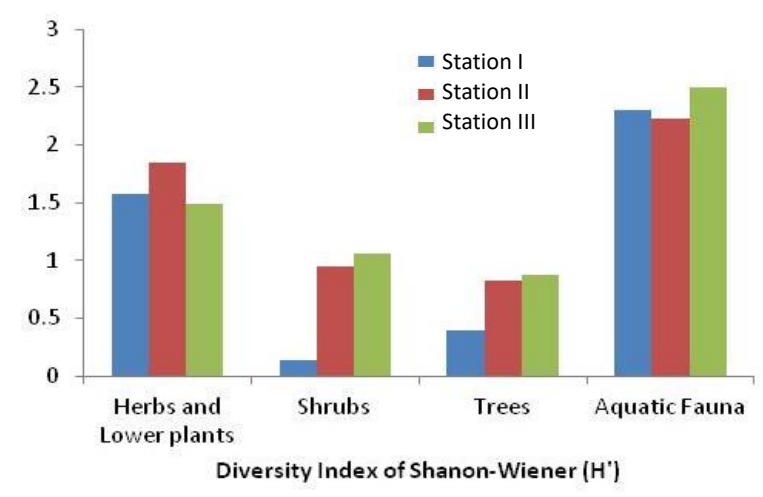

Figure 4. Diversity index of vegetation and aquatic fauna in mangrove area of Purworejo, Central Java, Indonesia

\section{Influential value of abiotic factors towards vegetation and aquatic fauna}

\section{Regression analysis on abiotic factors to biodiversity of mangrove vegetation}

The regression test placed diversity index of mangrove vegetation (in all phase) as dependent variable (y). The independent variables include temperatures $\left(\mathrm{x}_{1}\right), \mathrm{pH}\left(\mathrm{x}_{2}\right)$, dissolved oxygen $\left(\mathrm{x}_{3}\right)$ and salinity $\left(\mathrm{x}_{4}\right)$. According to the analysis, $\mathrm{R}^{2}$ value is 0.129 . It shows a weak effect of independent variables to dependent variable. The impact value is $12.9 \%$, and the rest is influenced by other factors which are included as research subjects.

Research on mangrove ecophysiology shows the adaptation on the intertidal environment. The environment has a heterogenic salinity, filled with water and lack of nutrients. Mangrove is not affected significantly by a change of salinity or an extreme salinity (Naidoo 2016). Mangrove is a halophyte facultative which undergo their lifecycle in a saline condition (Krauss and Ball 2013).

The changes of abiotic values give only very weak impact on diversity of mangrove vegetation. By the way, this condition is happened only in specific location but for 
all phase of plants. The impact value is probably changed in other location or on specific phase of plants as an effect of different dependence of each phase on abiotic condition.

$\mathrm{Y}=\mathrm{a}+\mathrm{b}_{1} \mathrm{x}_{1}+\mathrm{b}_{2} \mathrm{x}_{2}+\ldots .+\mathrm{b}_{\mathrm{n}} \mathrm{x}_{\mathrm{n}}$

Description:

$\mathrm{Y}$ is diversity index of mangrove vegetation on all phases of plants

$\mathrm{x}_{1}$ is temperatures, $\mathrm{x}_{2}$ is $\mathrm{pH}, \mathrm{x}_{3}$ is $\mathrm{DO}$, and $\mathrm{x}_{4}$ is salinity. $a$ and $b$ are constants of regression

The regression analysis is determined by the equation

$\mathrm{Y}=3.826-0.052\left(\mathrm{x}_{1}\right)-0.234\left(\mathrm{x}_{2}\right)+0.072\left(\mathrm{x}_{3}\right)+0.034\left(\mathrm{x}_{4}\right)$

\section{Regression analysis on abiotic factors against diversity index of aquatic fauna}

The regression test places diversity index of aquatic fauna as dependent variable (y). The independent variables include temperatures $\left(\mathrm{x}_{1}\right), \mathrm{pH}\left(\mathrm{x}_{2}\right)$, dissolved oxygen $\left(\mathrm{x}_{3}\right)$ and salinity $\left(\mathrm{x}_{4}\right)$. According to the analysis, $\mathrm{R}^{2}$ value is 0.032 , and it shows a weak effect of independent variables to dependent variable. The impact value is $3.2 \%$, and the rest is influenced by other factors which are included as research subjects. The changes of abiotic values give only a very weak impact on diversity of aquatic fauna. The impact is weaker than similar abiotic factors on vegetation as the effect of mobility of aquatic fauna.

$\mathrm{Y}=\mathrm{a}+\mathrm{b}_{1} \mathrm{x}_{1}+\ldots+\mathrm{b}_{\mathrm{n}} \mathrm{x}_{\mathrm{n}}$

$\mathrm{Y}$ is diversity index of aquatic fauna

$\mathrm{x}_{1}$ is temperatures, $\mathrm{x}_{2}$ is $\mathrm{pH}, \mathrm{x}_{3}$ is $\mathrm{DO}$, and $\mathrm{x}_{4}$ is salinity. $\mathrm{a}$ and $\mathrm{b}$ are constants of regression

The regression analysis is determined by the equation

$\mathrm{Y}=7.058-0.203\left(\mathrm{x}_{1}\right)+0.174\left(\mathrm{x}_{2}\right)-0.163\left(\mathrm{x}_{3}\right)+0.084\left(\mathrm{x}_{4}\right)-$ $0.270\left(\mathrm{x}_{5}\right)$

According to the research, 34 species of aquatic fauna are from mangroves area of Purworejo, and they result that the highest value of aquatic fauna is in Station 3 (ID 2.50). Pearson correlation test between vegetation and aquatic fauna shows that $\mathrm{R}$ value is 0.104 . The T-test determines a significant difference (sig 0.000) between abiotic factors and biotic condition which also shows the impact of changes between them. Further test with regression method also indicates a weak impact on changes in abiotic factors towards biotic condition $\left(\mathrm{R}^{2} 0.032\right)$.

Mangrove rehabilitation efforts were done properly, especially in relation with maintaining of the aquatic fauna diversity (macrobenthos). Research from Bosire et al. (2004) gave a result that an increase of macrobenthic diversity was happened as the effects of reforestation on the over-exploited mangroves. The step should be aligned with reduction of pollutant which considered to give similar impacts on increasingly of macrobenthic diversity (Leung and Cheung 2017).

Based the results of this study, it is concluded that Purworejo mangrove area must be protected in a sustainable way in order to protect its diverse aquatic fauna species for future generations.

\section{REFERENCES}

Alongi DM. 2002. Present state and future of the world's mangrove forests. Environ Conserv 29: 331-349.

Anneboina LR, Kumar KSK. 2012. Economic analysis of mangrove and marine fishery linkages in India. Ecosystem Services 24: 114-123.

Approaches and future directions. Hydrobiologia 685: 1-17.

Baran E. 1999. A review of quantified relationships between mangroves and coastal resources. Phuket Mar Biol Cent Res Bull 62: 57-64.

Bengen D. 2001. Coastal and Marine Ecosystems and Resources and Management in an Integrated and Sustainable. Proceedings of Integrated Coastal Management Training October 29-3 November 2001. Bogor. [Indonesian]

Bosire JO, Dahdouh-Guebas F, Kairo JG, Cannicci S, Koedam N. 2004. Spatial variations in macrobenthic fauna recolonisation in a tropical mangrove bay. Biodivers Conserv 13: 1059-1074

Carpenter KE, Niem VH. 1999. FAO Species Identification Guide for Fishery Purposes. The Living Marine Resources of The Western Central Pacific. Volume 3. Batoid fishes, chimaeras and bony fishes part 1 (Elopidae to Linophrynidae). Food and Agriculture Organization of United Nations, Rome.

Dsikowitzky L, Nordhaus I, Jennerjahn TC, Khrycheva P, Sivatharsan Y, Yuwono E, Schwarzbauer J. 2011. Anthropogenic organic contaminants in water, sediments and benthic organisms of the mangrove-fringed Segara Anakan Lagoon, Java, Indonesia. Mar Poll Bull 62: 851-862.

Eldeen IMS, Napiah NEM, Mohamad H. 2015. Efficacy of three mangrove plants against 5-lipoxygenase, acetylcholinesterase enzymes and five pathogenic bacterial strains. LIFE Intl J Health Life Sci 1 (1): 24-37.

Giri C, Zhu Z, Tieszen LL, Singh A, Gillette S, Kelmelis JA. 2008. Mangrove forest distributions and dynamics (1975-2005) of the tsunami-affected region of Asia. J Biogeogr 35: 519-528

Hardjowigeno S. 1989. Soil Science. Melton Putra, Jakarta. [Indonesian]

Ilman M, Dargusch P, Dart P, Onrizal. 2016. A historical analysis of the drivers of loss and degradation of Indonesia mangroves. Land Use Pol 54: 448-459.

Indriyanto. 2012. Forest Ecology. Bumi Aksara, Jakarta. [Indonesian]

Kathiresan K, Bingham BL. 2001. Biology of Mangroves and Mangrove Ecosystems. Advances In Marine Biology 40: 81-251.

Kovalenko KE, Thomaz SM, Warfe DM. 2012. Habitat complexity: approaches and future directions. Hydrobiologia 685 (1): 1-17.

Krauss KW, Ball MC. 2013. On the halophytic nature of mangrove. Trees 27: 7-11.

Kustanti A. 2011. Mangrove Forest Management. IPB Press, Bogor. [Indonesian]

Leung JYS, Cheung NKM. 2017. Can mangrove plantationenhance the functional diversity of macrobenthic community in polluted mangroves? Mar Poll Bull 116: 454-461.

Local Government of Purworejo. 2011. Purworejo District Regulation No. 27 of 2011 on Spatial Planning of Purworejo District Year 20112031. Local Government of Purworejo, Purworejo. [Indonesian]

Marwoto RM, Isnaningsih NR. 2014. A review of the diversity of fresh water molluscs in several natural ponds in the Ciliwung-Cisadane Watershed. Berita Biologi 13 (2): 181-189. [Indonesian]

Minister of Environmental. 2004. Decree of Minister of Environmental Number 201 Year 2004 on Standard Criteria and Guidelines for Determination of Mangrove Damage. Ministry of Environment, Jakarta. [Indonesian]

Monsef HA, Smith S. 2008. Site selection for mangrove plantations along the Egyptian Red Sea Coast. World Appl Sci J 3 (7): 740-747.

Naidoo G. 2016. The mangroves of South Africa: an ecophysiological review. South African J Bot 107: 101-113

Ng PKL, Sivasothi N. 2001. A Guide to Mangroves of Singapore. Singapore Science Center, Singapore.

Noor YR, Khazali M, Suryadiputra INN. 2012. Guide to Introduction of Mangrove in Indonesia. Wetlands International Indonesia Programme, Bogor. [Indonesian]

Odum EP, Barrett GW. 2009. Fundamentals of Ecology. 5th ed. Cengage Learning, Melbourne

Onrizal. 2008. Guide to Introduction and Vegetation Analysis of Mangrove Forest. Universitas Sumatera Utara. Medan. [Indonesian]

Oudenhoven APE, Siahainenia AJ, Sualia I, Tonneijk FH, van der Ploeg S, de Groot RS, Alkemade R, Leemans R. 2015. Effects of different 
management regimes on mangrove ecosystem services in Java, Indonesia. Ocean Coast Manag 116: 353-367.

Pong-Masak PR, Pirzan AM. 2006. Macrozoobenthos Community at the Pond Culture Area in Malakosa Coastal, Parigi Moutong, Central Sulawesi. Biodiversitas 7 (4): 354-360. [Indonesian]

Regional Development Planning Board of Purworejo. 2016. Regional Featured Potential of Purworejo. Purworejo. Regional Development Planning Board of Purworejo, Purworejo. [Indonesian]

Spalding M, Kainuma M, Collins L. 2010. World Atlas of Mangrove. Earthscan, London, UK.

Sreenivasa RM, Teja G, Sirisha IR, Yedukondala RP. 2015. Screening of antimicrobial activity of mangrove plant Acanthus ilicifolius onshrimp and fish pathogens. Asian J Plant Sci Res 5 (5): 1-3.
Strong EE, Gargominy O, Ponder WP, Bouchet P. 2008. Global diversity of Gastropods (Gastropoda; Mollusca) in freshwater. Hydrobiologia 595: 149-166.

Supardjo MN. 2008. Identification of mangrove vegetation at Segoro Anak Selatan, Alas Purwo National Park, Banyuwangi, East Java.Jurnal Saintek Perikanan 3 (2): 9-15. [Indonesian]

Supriharyono. 2007. Ecosystem Conservation of Biological Resources. Pustaka Pelajar, Yogyakarta. [Indonesian]

Tomlison PB. 1994. The Botany of Mangroves. Cambridge University Press, Cambridge, UK

Zakaria M, Rajpar MN. 2015. Assessing the fauna diversity of Marudu Bay Mangrove Forest, Sabah, Malaysia, for future conservation. Diversity 7 (2): 137-148. 